\title{
VERWYSINGS NA DIE WOORDTEKSTE VAN AFRIKAANSE VOLKSLIEDERE IN DIE ROMAN AGAAT VAN MARLENE VAN NIEKERK
}

\author{
Heinrich van der Mescht \\ Departement Musiek, Universiteit van Pretoria, Pretoria, 0002
}

\section{References to the word texts of Afrikaans folk songs in the novel Agaat by Marlene van Niekerk}

Marlene van Niekerk’s Afrikaans novel Agaat (2004) has won many prizes, amongst them the Hertzog Prize, and has been translated into English and Dutch. During the course of the novel many references are made to music, be it religious, classical, popular or Afrikaans folk music. In this article, quotations from the word texts of Afrikaans folk songs (mostly from the F.A.K. Songbook) are discussed. These references are often used by the main character Agaat when dealing with Milla, her bed-ridden mistress, to whom she now has to attend to during her final days. The references are mostly employed in an ironic, insensitive and cruel manner. In this way Agaat expresses the resentment she feels towards Milla. Some silly quotations of Afrikaans folk songs, however, also give the main characters Agaat and Milla some respite from the difficult situation in which they find themselves. Through these means the Afrikaans cultural milieu in which the novel is set is illuminated.

Key words: Afrikaans folk songs, Agaat, F.A.K. Songbook, Marlene van Niekerk, references

Marlene van Niekerk se roman Agaat (2004) het baie literêre pryse gewen, onder andere die Hertzogprys, en is in Engels en Nederlands vertaal. Tydens die verloop van die roman word daar baie verwysings na musiek gemaak, hetsy gewyde, klassieke, populêre of Afrikaanse volksliedere. In die artikel word aanhalings uit die woordtekste van Afrikaanse volksliedere (meesal uit Die F.A.K.-Volksangbundel) bespreek. Hierdie verwysings word dikwels deur die hoofkarakter Agaat gebruik wanneer sy werk met Milla, haar bedgebonde meesteres, wat sy nou moet versorg tydens Milla se laaste dae. Die verwysings word meesal op 'n ironiese, onsensitiewe en wrede manier aangewend. Hierdeur toon Agaat die wrewel wat sy teenoor Milla voel. Party lawwe aanhalings van Afrikaanse volksliedere gee egter ook aan die hoofkarakters Agaat en Milla verligting van die moeilike omstandighede waarin hulle hulle bevind. Deur 
die voortdurende aanhaling word die Afrikaanse kulturele milieu waarin die roman afspeel, verhelder.

Sleutelterme: Afrikaanse volksliedere, Agaat, Die F.A.K.-Volksangbundel, Marlene van Niekerk, verwysings

\section{Inleiding}

Marlene van Niekerk se roman Agaat (2004) ${ }^{1}$ is in 2006 met die Hertzogprys vir letterkunde bekroon. Dit het reeds voorheen die Universiteit van Johannesburg-, die W.A. Hofmeyr- en die M-Net-prys verower. ${ }^{2}$ In 2006 is die Engelse vertaling (deur Michiel Heyns) onder die titel Agaat in Suid-Afrika gepubliseer ${ }^{3}$ en in 2007 het dit onder die titel The Way of the Women (vergelyk "die weg van die vroue") ${ }^{4}$ in Engeland verskyn. ${ }^{5}$ Die Nederlandse vertaling (deur Riet de Jong-Goossens) is in 2006 in Nederland gepubliseer. ${ }^{6}$ Die roman het byna uitsluitlik baie positiewe resensies ontvang, maar daar was ook kritiek. Salafranca skryf byvoorbeeld: "[T]he story is depressing in the extreme, yet I have read other stories equally depressing but far more readable. This is mired in the confines of Milla's dying head, and it's all simply too unrelenting."

Die roman Agaat het so 'n groot impak gemaak dat 'n groot verskeidenheid aspekte daarvan in artikels en verhandelings ondersoek is. In antwoord op 'n artikel deur Johann Rossouw, skryf Anton van Niekerk van die Universiteit van Stellenbosch oor die politieke situasie van die Afrikaner soos uitgebeeld in Agaat. $^{8}$ Andries Wessels van die Universiteit van Pretoria vergelyk die gegewe in Agaat met sekere Ierse romans waarin die Big House-tema voorkom. ${ }^{9}$ Hoe kommunikasie deur taal bewerkstellig word, is die onderwerp van 'n artikel deur Willie Burger van die Universiteit van Johannesburg. ${ }^{10}$ Johan van der Walt van die Universiteit

\footnotetext{
M. van Niekerk, Agaat (Kaapstad, 2004).

D. Steinmair, Op prys gestel, Boeke Insig 1, 2007, pp. 28, 31.

M. van Niekerk, Agaat (Kaapstad, 2006).

M. van Niekerk, Agaat (2004), pp. 187, 606.

M. van Niekerk, The way of the women (Londen, 2007).

M. van Niekerk, Agaat (Amsterdam, 2006).

A. Salafranca, Agaat, The Star, 2007-03-01, p. 10.

A. van Niekerk, Oor die wegbly van die “jollie bobbejaan”, Rapport, 2005-02-06, p. 19.

A. Wessels, Marlene van Niekerk se Agaat as inheemse Big House-roman, Tydskrif vir Letterkunde 43(2), 2006, pp. 31-45.

10 W. Burger, Die storie in die eerste sin, Byvoegsel By tot Beeld, 2008-08-02, p. 14. Kyk ook W. Burger, Deur 'n spieël in 'n raaisel: Kennis van die self en die ander in Agaat van Marlene van Niekerk, Tydskrif vir Taalonderrig 40(1), 2006, pp. 178-194; W. Burger, Appèl op die leser, De Kat, Julie 2006, pp. 112-113.
} 
van Glasgow het op 7 Augustus 2008 'n referaat oor “Agaat's Law: Reflections on law and literature with reference to Marlene van Niekerk's novel Agaat" by die Regskool van die Universiteit van die Witwatersrand in Johannesburg gelewer. 'n Verdere regsblik is Melodie Nöthling Slabbert van die Universiteit van Suid-Afrika se "Justice, justification and justifiability in Marlene van Niekerk’s Agaat: a legal-literary exploration."11 Agaat word ook bespreek in Mark Sanders, toe van die Universiteit van New York en tans van die Brandeis-Universiteit, se "Miscegenations: Race, culture, phantasy." ${ }^{12}$ Hierby sluit Loraine Prinsloo en Andries Visagie, toe van die Universiteit van KwaZulu-Natal, aan met hulle artikel oor die representasie van die bruin werker as die ander. ${ }^{13}$ Prinsloo het ook 'n M.A.-verhandeling oor Agaat as postkoloniale plaasroman voltooi. ${ }^{14}$ Cheryl Stobie kyk vanuit 'n religieuse perspektief in haar "'Speaking with our spirits': The representation of religion in Marlene van Niekerk’s Agaat” en "Ruth in Marlene van Niekerk’s Agaat” waarin sy verbande trek met die verhaal in die Bybelboek Rut. ${ }^{15}$ Die struktuur van die roman kry aandag in 'n referaat van Louise Viljoen van die Universiteit van Stellenbosch oor die rol van die dagboek as struktuurelement in Agaat. ${ }^{16}$ By die Universiteit van Utrecht het Rosemarie Buikema in 2006 in haar professorale intreerede by die Universiteit van Utrecht 'n vergelyking probeer tref tussen J.M. Coetzee se Disgrace en Marlene van Niekerk se Agaat. ${ }^{17}$ Maryke Henn het in 2009 'n MA-graad aan die Universiteit van Stellenbosch voltooi met “'n Strukturele en verteltegniese ondersoek na die representasie van die

11 M. Nöthling Slabbert, Justice, justification and justifiability in Marlene van Niekerk’s Agaat: a legalliterary exploration, Fundamina: A Journal of Legal History 12(1), 2006, pp. 236-250.

12 M. Sanders, Miscegenations: race, culture, phantasy, Journal of the Association for the Study of Australian Literature (Special issue 2008: The Colonial Present), 2008, pp. 10-36.

13 L. Prinsloo \& A. Visagie, Die representasie van die bruin werker as die ander in Marlene van Niekerk se postkoloniale roman Agaat (2004), Stilet 19(2), 2007, pp. 43-62.

14 L. Prinsloo, Marlene van Niekerk se Agaat (2004) as postkoloniale plaasroman. M.A.-verhandeling, Universiteit van KwaZulu-Natal, Durban, 2006.

15 C. Stobie, 'Speaking with our spirits': The representation of religion in Marlene van Niekerk's Agaat, Colloquium on religion and spirituality in a postcolonial context, Centre for African Literary Studies, University of KwaZulu-Natal, Pietermaritzburg, 29-31 Januarie 2007, http://www.open.ac.uk/Arts/ ferguson-centre/Events/postcolspirs-workshopprog-jan07.pdf, 2008-09-14; C. Stobie, Worlds, texts, critics: Ruth in Marlene van Niekerk's Agaat, referaat gelewer by die AUETSA-konferensie, Durban, 9-11 Julie 2007, http://academic.sun.ac.za/English/AUETSA2007/AUETSA\%20Conference\%20 Draft\%20Programme.doc, 2008-09-14.

16 L. Viljoen, Die dagboek as struktuurelement in Agaat, referaat gelewer by die kongres van die Afrikaanse Letterkundevereniging, Bloemfontein, 2008-09-09.

17 R. Buikema, Theft and flight in the arts, intreerede aan die Universiteit van Utrecht, 2006-11-10. Vertaal deur Christien Franken. http://www.genderstudies.nl/cms/uploads/Inaugural_lecture_professor_ Buikema.pdf, 2008-09-12. 
vroulike subjek" in Agaat. ${ }^{18}$ Die Engelse weergawe van Agaat is verder deur Ester Levinrad aan ontleding onderwerp. ${ }^{19}$

Hierdie lang lys maak dit duidelik dat die roman reeds kort na sy publikasie 'n groot verskeidenheid response op verskillende vakgebiede en navorsingsterreine ontlok het.

Van Niekerk verwys in Agaat gereeld na kunstige en na mooi dinge; so byvoorbeeld na borduurwerk (wat ook op die omslag van die boek verskyn). Daar is egter nog te min aandag geskenk aan een van die treffendste eienskappe van die roman: die voortdurende verwysings na musiek. ${ }^{20}$ Wat hierdie aspek betref, kan Agaat vergelyk word met die literêre werk van George Eliot, "saturated as it is with musical references". ${ }^{21}$

Die onderwerpe van die musiekverwysings in Agaat kan in vyf hoofgroepe verdeel word:

- volksliedere;

- ligte liedere;

- psalms, gesange en hallelujaliedere;

- verwysings na spesifieke komposisies uit die klassieke repertorium; en

- verskuilde, vertaalde aanhalings van versreëls uit getoonsette gedigte uit die Duitse kunsliedrepertorium.

Daar is nog nie 'n studie onderneem oor die uiters belangrike rol wat verwysings na volksmusiek in Agaat vervul nie. Dit is die doel van hierdie artikel om die volgende navorsingsvraag te beantwoord: "Hoe word verwysings na die woordtekste van Afrikaanse volksliedere gebruik om die karakters Agaat en Milla en hulle omstandighede in Agaat te teken?” Die artikel sal dus hoofsaaklik op die verhouding tussen Agaat en Milla konsentreer, alhoewel musiekverwysings na Milla se man (Jak) en seun (Jakkie) ook vermeld sal word. Om hierdie doel te bereik, het ek eers vasgestel watter artikels en verhandelings oor Agaat geskryf is. Ek het die roman ontleed en die verwysings na Afrikaanse volksliedere nagegaan en vergelyk met bronne soos Die

18 M. Henn, 'n Strukturele en verteltegniese ondersoek na die representasie van die vroulike subjek in Marlene van Niekerk se Agaat (M.A.-verhandeling, Universiteit van Stellenbosch, 2009).

19 E. Levinrad, "The weight of my skeleton is my only honesty": Language and the speaking body in Marlene van Niekerk's Agaat (M.A.-verhandeling, Universiteit van Stellenbosch, 2010).

20 Vergelyk H. van der Mescht, Verwysings na klassieke musiek in Marlene van Niekerk se roman Agaat, Litnet Akademies 6(3), 2009, 16 pp.

21 P. Weliver, Women musicians in Victorian fiction, 1860-1900: Representations of music, science and gender in the leisured home (Aldershot, 2000), p. 16. 
F.A.K.-Volksangbundel ${ }^{22}$ en Goue Gerf. ${ }^{23}$ Verskeie bronne geskryf deur kenners op die gebied van verwysings (na musiek onder andere) in letterkundige werke (Barthes, Clapp-Itnyre, Fuller, Kristeva, Losseff, Lustig, Weliver) is geraadpleeg. Jan Bouws het 'n baie groot bydrae tot navorsing oor die Afrikaanse volkslied gelewer. ${ }^{24}$ Sy boek Die volkslied, deel van ons erfenis bevat byvoorbeeld besprekings van spesifieke Afrikaanse volksliedere waarin sowel die woordteks as die melodie afgedruk en behandel word. In hierdie artikel is dit egter uitsluitlik die inkorporering van die woordteks waaraan aandag geskenk word, en nie die melodie nie. Matilda Burden verskaf 'n waardevolle oorsig oor die eienskappe van die Afrikaanse volkslied en bevind dat die Afrikaanse volkslied soos gesing deur die "bruin Afrikaanssprekende gemeenskap" met enkele uitsonderings (woordgebruik en ritmiese vertolking) dieselfde kenmerke openbaar as die liedere soos gesing deur blankes. ${ }^{25}$ Hierdie uitspraak is belangrik binne die konteks van Agaat, aangesien die karakter Agaat volgens kleur aan die bruin gemeenskap behoort, maar van kleins af by blankes grootgeword het. Haar voordrag van Afrikaanse volksliedere sou deur woordgebruik tog eienskappe van die bruin gemeenskap (haar mede-werkers op die plaas) kon bevat. Martjie Bosman gee 'n historiese oorsig oor die ontwikkeling van versamelings Afrikaanse volksliedere. ${ }^{26}$

Die begrip "verwysing” omvat die Engelse woorde "reference” en "allusion”. 'n Verwysing kan 'n "literêre verwysing”" wees, in welke geval die literêre teks na 'n ander literêre teks verwys, maar dit kan ook enige ander teks wees, byvoorbeeld die tekste van volksliedere, soos in hierdie artikel.

Johann Gottfried Herder (1744-1803), die samesteller van Stimmen der Völker in Liedern (postuum gepubliseer in 1807), was die eerste persoon wat die term "Volkslied” gebruik het. ${ }^{27}$ Die volkslied is 'n eenvoudige gedig, dikwels met rymende versreëls, wat saam met sy melodie ontstaan het en daarna deur die volk as algemene besit oorgeneem is. So spreek dit die "Volksgeist", die geloof uit in die gees van

22 Die F.A.K.-Volksangbundel (Pretoria, 1937); Die F.A.K.-Volksangbundel (Kaapstad, 1958), FAKSangbundel (Johannesburg, 1979).

23 M. Casaleggio (hoofred.), Goue gerf (Johannesburg, 1970).

24 J. Bouws, Die Afrikaanse volkslied (Johannesburg, 1958); Woord en wys van die Afrikaanse lied (Kaapstad, 1961); Die volkslied, weerklank van 'n volk se hartklop (Kaapstad, 1962); Die volkslied, deel van ons erfenis (Kaapstad, 1969).

25 M. Burden, Kenmerke van die Afrikaanse volkslied, Suid-Afrikaanse Tydskrif vir Kultuurgeskiedenis 7(2), 1993, pp. 34-38.

26 M. Bosman, Die FAK-fenomeen: populêre Afrikaanse musiek en volksliedjies, Tydskrif vir Letterkunde 41(2), 2004, pp. 23-28.

27 G. von Wilpert, Sachwörterbuch der Literatur (Stuttgart, 1964), pp. 767-768; H.D. Schlosser, dtv-Atlas Deutsche Literatur (München, 2010), p. 156. 
die volk as aktiewe, skeppende krag. ${ }^{28}$ Weens "die vervorming van woorde in die volksmond" is die woordteks van 'n spesifieke volkslied nie altyd gestandaardiseer en konsekwent nie. ${ }^{29}$ Die digter en komponis van die volkslied is gewoonlik nie bekend nie. Ná Herder het Achim von Arnim (1781-1831) en Clemens Brentano (1778-1842) 'n uiters belangrike rol gespeel met hulle Des Knabens Wunderhorn, 'n versameling van 723 volksgedigte ${ }^{30}$ wat tussen 1805 en 1808 verskyn het. ${ }^{31}$ Die eerste bundel is opgedra aan Goethe (1749-1832) wat in 1770, deur sy ontmoeting met Herder in Straatsburg (Strassburg), 'n belangstelling in volksliedere ontwikkel het ${ }^{32}$ en later self volksliedere versamel het. Arnim en Brentano moes baie kritiek verduur omdat hulle aanpassings aan sommige van die tekste aangebring het, byvoorbeeld deur hulle eie versreëls by te voeg. Volgens Wilpert is die gedigte eerder "freie Bearbeitung und Umdichtung" 33 (vrye verwerking en herdigting). Dit is in werklikheid 'n wesenlike eienskap van die volksliedwording van 'n nuwe lied, naamlik dat dit deur die toedoen van 'n verskeidenheid persone geleidelik veranderings ondergaan, wat sowel melodie as woordteks kan betrek.

Dit word gou duidelik dat die intertekstuele verbande met musiek meesal versluierd in Agaat aangebied word. Van Niekerk verskaf op die bladsy ná die titelblad die volgende gedeeltelike erkenning van bronne:

Ek erken die direkte en indirekte gebruik in die stemme van karakters - soms met verwysing, soms sonder - van teksmateriaal uit Afrikaanse en ander (plaas)romans sowel as van gedigte van onder andere Elisabeth Eybers en Wilma Stockenström. ${ }^{34}$

Van Niekerk dui nie deur middel van aanhalingstekens of ander middele aan wanneer sy 'n teks aanhaal nie. Dit word dus nie tipografies uitgelig nie. Die aangehaalde teks word meesal direk in haar teks ingelyf. Die wyse waarop Van Niekerk ongemerk na die aanhaling oorgaan, is een van die opwindendste aspekte van haar verwysingstegniek.

28 Die beroemde musiekwetenskaplike Carl Dahlhaus in D. Beard \& K. Gloag, Musicology: The key concepts (Londen, 2005), p. 119.

$29 \quad$ M. Burden, Kenmerke van die Afrikaanse volkslied (1993), p. 34.

$30 \quad$ H. Rölleke, Des Knaben Wunderhorn: Alte deutsche Lieder (Stuttgart, 2006), band 3, p. 477. Die oorspronklike titelblad van die eerste band dra die jaartal 1806.

31 'n Uitstekende uitgawe is dié in drie bande met omvangryke kommentaar deur Heinz Rölleke, Des Knaben Wunderhorn: Alte deutsche Lieder (2006).

32 G. von Wilpert, Deutsches Dichterlexikon (Stuttgart, 1963), p. 247.

33 G. von Wilpert, Deutsches Dichterlexikon (1963), p. 20.

34 M. van Niekerk, Agaat (2004). 
In onderhoude met Van Niekerk kon die skrywer van hierdie artikel waardevolle inligting inwin. Een onderhoud is opgeneem, toepaslike uittreksels is getranskribeer en belangrike gesigspunte is geabstraheer. Van Niekerk was bereid (en het verkies) om vrae ook skriftelik te beantwoord. Verdere vrae is per e-pos en telefoon gestel. ${ }^{35}$ Vir hierdie artikel gebruik ek die 1958-uitgawe van die Die F.A.K.-Volksangbundel (Kaapstad, 1958) as die verstek-teks. ${ }^{36}$ Dit is die uitgawe waarmee Van Niekerk grootgeword het, ${ }^{37}$ en ook waarmee die karakters Milla en Agaat grootgeword het. Ek maak wel verwysings na latere uitgawes van Die F.A.K.-Volksangbundel.

\section{Agtergrond van die studieterrein}

Volgens Fuller en Losseff word die interdissiplinêre studie van musiek en letterkunde reeds meer as vyftig jaar deur musiekwetenskaplikes en letterkundiges onderneem. ${ }^{38}$ Fuller en Losseff meld dat die meeste van die werk op musiekkomposisies fokus: hulle verband met narratiewe en ander literêre strukture, die woordtoonverhouding in liedere en operas, of modelle van die interaksie tussen die gemeenskap en die kunswerk. Ander navorsers konsentreer op letterkundige werke waarin die musiekpraktyk beskryf word.

Die huidige artikel wil egter, in die letterkundige teks Agaat, na die rol en funksie van verwysings na spesifieke volksliedere kyk. Aangesien musiek-aktiwiteite binne kulturele verband ook aandag kry, sal die studie dus ook poog om 'n "contextualized study of music" te wees. ${ }^{39}$ Hierin speel intertekstualiteit 'n belangrike rol, soos opgesom deur Barthes:

We know now that a text is not a line of words releasing a single "theological" meaning (the "message" of the Author-God) but a multi-dimensional space in which a variety of writings, none of them original, blend and clash. The text is a tissue of quotations drawn from the innumerable centres of culture. [...] His [the author's] only power is to mix writings, to counter the ones with the others $[\ldots] .^{40}$

\footnotetext{
35 M. van Niekerk, onderhoud [met skrywer van artikel], Stellenbosch, 2007; M. van Niekerk, geskrewe antwoorde op vrae [van skrywer van artikel], 2007; M. van Niekerk, informasie per e-pos [aan skrywer van artikel], 2008; M. van Niekerk, telefoononderhoud, 2010-10-29.

36 H. Gutsche, W.J. du P. Erlank \& S.H. Eyssen, Die F.A.K.-Volksangbundel (1958).

37 M. van Niekerk, telefoononderhoud, 2010-10-29.

38 S. Fuller \& N. Losseff (reds.), Introduction, The idea of music in Victorian fiction (Aldershot, 2004), p. xiii.

39 P. Weliver (red.), The figure of music in nineteenth-century British poetry (Aldershot, 2005), p. 5.

40

R. Barthes, The death of the author, Image Music Text (Glasgow, 1977), pp. 142-148.
} 
Daar sal aangetoon word hoe Van Niekerk haar eie teks ("a tissue of quotations drawn from the innumerable centres of culture”) vermeng ("blend and clash”) met aanhalings uit die woordteks van Afrikaanse volksliedere.

Weliver, in haar inleiding tot The Figure of Music in Nineteenth-Century British Poetry, het die volgende mening oor analisemetodes, wat op hierdie artikel van toepassing is:

Multiple strategies are viable for understanding a single subject (music and poetry), because a subject is now seen as plural; it is understood not only through many texts, but also through many approaches. ${ }^{41}$

\section{Tonele in die roman waar aspekte van die Suid-Afrikaanse kultuur deur musiek uitgebeeld word}

In 'n gesprek met Sonja Loots het Van Niekerk verklaar dat sy “doelbewus probeer het om 'n sekere soort kultuur of erfenis te dokumenteer. [...] Met Agaat wou ek 'n omgewing dokumenteer wat aan die verdwyn en verander is, maar wat ek baie goed geken het. [...] Natuurlik word die kultuur of erfenis bevraagteken [...]." ${ }^{42}$

In hierdie afdeling sal verskillende tonele bespreek word waarin musiek 'n deurslaggewende rol speel.

Die kompleksiteit en omvang van die musiekverwysings in Agaat word goed geïllustreer in een van die gedagtestroompassasies waarin verwysings na Afrikaanse liedjies en ligte liedere voorkom. Die collage-agtige passasie beskryf ' $n$ badtoneel waar die hulpelose Milla deur Agaat gehelp moet word:

waterstoel steenkoolswart hysgeluid op hoё C seepbestand geïnsuleer roesvry sinteties aangeklee sodat dit nie die bad sal krap gewigsgrens 200 kilo vir dikker vetter lammes maar 'n dunnetjie 'n liggewig om haar te hys 'n grap om te laat sak 'n laggertjie om haar te bad sondagspeletjies op 'n dubbeldekkerseteltjie minus armleunings vasgeskroewe aan die waterkant laer as die rystoel sodat sy moeiteloos daarin kan glip aquasitz deur julius bach soos mens van duitsers kan verwag sitplekgordel nekring hidroulies gly ons bootjie ${ }^{43}$ druk die knop dan styg sy op gehewel oor die rand en weer laat

$41 \quad$ P. Weliver (red.), The figure of music in nineteenth-century British poetry (2005), p. 16.

42 S. Loots, Nog in die kielsog, onderhoud met Marlene van Niekerk, Rapport, 2004-11-28, p. 4.

43 Van Niekerk gebruik nie vetdruk in Agaat nie. Daarom word vetdruk in hierdie artikel aangewend om verwysings na volksliedere uit te lig. Van Niekerk verwys hier op ironiese wyse na die rustige, romantiese liedjie Die bootjie na Kamma-land met die eerste reëls "Hoe sag gly ons boodjie, en wieg heen en weer”. Dit vorm deel van die beskrywing van hoe Milla in die bad in gehelp word met die 
sak tot op die bodem 'n ligte skok verstel die rug lê agtertoe ontspan anders as die binneband waarin sy op die roerkuil rondomtalie wat hoor sy daar? 'n demonstrasieles? dokter pak weer stoeltjie uit agent van bach in afrika? maar hy is lankal weg! wat hoor sy in die diepte van die nag? oor en oor die hysgeluid op en dwars en af sewentig maal sewe keer? sy begewe haar in ibot mute medium cruise af in die donker gang wie's daar in haar bad alleen? nek geklem in hoepels gordels vasgetrek slapend in die waterstoel? sy slaan alarm met haar hoenderpoot waltzing mathilda jesu joy of man's desiring blou donau jeepers creepers where'd you get those peepers strangers in the night what a wonderful world ${ }^{44}$ wie dink dit alles uit vir die stommes? die lopendes die walsendes die verlangendes? u oproep sal beantwoord word haar redder is buite bereik in die droë badkuip hande op die bors gevou die kleintjie in die grote toegehou bene reguit enkels bymekaar swart en wit en bruin hoe ryk haar kleur hoe sag haar vel in die strak wit wieg 'n kapsulestoel 'n ruimtevlug staan op badmeester! word wakker hekwagter! dis nog nie tyd vir die laaste vaart sing vir my as jy kan jol soos ek kan jol verby die robotnote sing uit volle bors 'n menseliedjie sing!' 'n plat gesang in teen hierdie uitgerekte vrekte. ${ }^{45}$

Die verwysings na volksliedere en ander aspekte van die tydgenootlike Suid-Afrikaanse kultuur waarin musiek 'n rol speel, plaas die Agaat-teks sterk in 'n kulturele konteks. Van Niekerk verwys byvoorbeeld na die TV-program Noot vir Noot ${ }^{46}$ waarin 'n vasvra oor ligte liedjies plaasvind en genooide kunstenaars meesal in Afrikaans sing. Daar is bedekte kritiek op die populariteit van die program, aangesien Agaat dit nie in Milla se kamer wil toelaat nie. Ook die radioprogram U eie keuse, die weeklikse stapelvoedsel van ligte klassieke musiek vir baie Afrikaanssprekende luisteraars, word genoem.

Milla se liefde vir klassieke musiek het veroorsaak dat sy haar kêrel (en later man) Jak dwing om saam met haar liederaande in die Konservatoriumsaal op Stellenbosch by te woon, ${ }^{47}$ iets wat as 'n meer intellektuele aktiwiteit beskou word.

Dit is duidelik dat die Afrikaanse kultuur (soos die meeste ander kulture) deurspek is met sang. Dit is asof daar weinig geleenthede kan plaasvind sonder dat

hulp van 'n elektriese toestel (“ons bootjie”). Kyk H. Gutsche et al., Die F.A.K.-Volksangbundel (1958), p. 245. Die teks is van Eitemal en die melodie van die Duitse komponis C.M. von Weber (1786-1826).

44 Hier word na 'n aantal (meesal) ligte liedere verwys.

45 M. van Niekerk, Agaat (2004), pp. 578-579.

46 M. van Niekerk, Agaat (2004), p. 20.

47 M. van Niekerk, Agaat (2004), p. 51. 
iemand moet sing. In 1984 word Milla en Jak uitgenooi na 'n medaljeparade by die lugmagbasis Ysterplaat. By die geleentheid is daar “'n noenmaal met koorsang in 'n saal en in die middag 'n militêre lugskou. Jakkie sou sing en in 'n formasievlugeskader optree.”48 Die teenstelling van die twee aktiwiteite (koorsang, militêre lugskou) is hier opvallend. "Toe is die eresaluut afgevuur, die taptoe geblaas, die orkes het gespeel, Die Stem is gesing”. ${ }^{49}$

Later was daar nog meer musiek en die besef dat haar seun vir haar 'n vreemdeling geword het, onherkenbaar tussen andere:

Die koor het drie nommertjies gesing. Uit die chaos van die eeue, en toe 'n medley met Wanneer kom ons troudag, Gertjie en ander liedjies, en toe die viskelkie opgedra word, 'n kanon, Vir spys en drank sê ons U Dank, ons loof u Naam, o Heer. Die dirigent het vir die mense in die saal gewys waar om in te val en saam te sing. Jy kon nie Jakkie se stem uitken tussen die tenore nie. Jy kon hom nie eers uitken daar op die rostrum nie, hulle het almal eenders gelyk..$^{50}$

Dit gaan die leser nie verby nie dat die liedere wat gesing is almal in Afrikaans was. Dit verwys na die eensydige Afrikaanse en godsdienstige opset van die Suid-Afrikaanse lugmag se sogenaamde koor- en konsertgroep van die apartheids-era.

'n Partytjie op Grootmoedersdrift gaan vanselfsprekend gepaard met musiek vir die dansery. ${ }^{51}$

Wessels toon aan dat die verwysing na Die stem van Suid-Afrika sowel Agaat as Milla se Afrikanererfenis verteenwoordig. ${ }^{52}$ Die seun Jakkie se beskrywing van Milla se begrafnis is soos verwag, maar met skuldgevoelens wat moontlik na vore kom. Die aanhaling bevat woorde van die voormalige amptelike volkslied:

Gaat wat die mense by die graf die derde versie van Die Stem laat sing: ... by die klink van huw'liksklokkies, by die kluitklap op die kis.

En toe's al die oë op mý by: ... streel jou stem ons nooit verniet nie, weet jy waar jou kinders is. Op jou roep seg ons nooit nee nie, seg ons altyd, altyd ja! ${ }^{53}$

\footnotetext{
M. van Niekerk, Agaat (2004), p. 514.

M. van Niekerk, Agaat (2004), p. 519.

M. van Niekerk, Agaat (2004), p. 520.

M. van Niekerk, Agaat (2004), pp. 637-638.

A. Wessels, Marlene van Niekerk se Agaat as inheemse Big House-roman, Tydskrif vir Letterkunde 43(2), 2006, p. 39.

53 M. van Niekerk, Agaat (2004), p. 701.
} 
Lustig het aangedui hoe die klavier verskillende belangrike rolle in die konstruksie van heelparty 19de-eeuse romans speel. ${ }^{54}$ Sy verwys na Sense and sensibility (Jane Austen, 1811), Emma (Austen, 1816), Vanity Fair (Thackeray, 1847-1848), David Copperfield (Dickens, 1849-1850), The mill on the Floss (George Eliot, 1860), Far from the Madding Crowd (Thomas Hardy, 1874), The Mayor of Casterbridge (Hardy, 1886) en Jude the Obscure (Hardy, 1895). Lustig skryf:

In the Victorian novel, the piano offers a point where woman meets man, nature meets culture and art meets artifice; its role in determing these categories comments on the construction of subjectivity in the largest sense. ${ }^{55}$

Die klavier speel ook 'n belangrike rol in die kulturele definisie van die plaasopstal op Grootmoedersdrif. Dit is 'n objek wat die verhewe ontwikkelingsvlak van die gesin (moet) weerspieël. As sodanig verteenwoordig die klavier dus 'n stel konvensies, kodes en ideologieë (“a set of conventions, codes and ideologies”) ${ }^{56}$ van die tydperk.

\section{Verwysings na Afrikaanse volksliedere}

Oor haar deeglike voorbereiding vir die inkorporering van verwysings na godsdienstige liedere en Afrikaanse volksliedere verklaar Van Niekerk:

Ek het baie gesit met psalms en gesange waarvan ek die woorde al vergeet het, ure lank. Soos 'n hert in dorre streke. Bly by my Heer terwyl die skadu's daal. Ek het ook feitlik die hele FAK deurgesing. ${ }^{57}$

Clapp-Itnyre begin haar artikel oor George Eliot se The Mill on the Floss met die volgende woorde: "Victorians evoked folk songs as nostalgic reminders of an English way of life that was fast disappearing." ${ }^{\text {8 }}$ Vir Milla, waar sy op haar doodsbed lê, bring die verwysing na volksliedere die verband met 'n era wat besig is om vir haar verby te gaan. Uittreksels uit die woordteks van Afrikaanse volksliedere word gereeld in

54 J. Lustig, The piano's progress: The piano in play in the Victorian novel, in S. Fuller \& J. Losseff (reds.), The idea of music in Victorian fiction (2004), pp. 83-104.

55 J. Lustig, The piano's progress (2004), p. 103.

56 S. Fuller \& N. Losseff (reds.), Introduction, The idea of music in Victorian fiction (2004), p. xx; J. Lustig, The piano's progress (2004), pp. 103-104.

57 S. Loots, Nog in die kielsog, onderhoud met Marlene van Niekerk, Rapport, 2004-11-28, p. 4.

58 A. Clapp-Itnyre, Indecent musical displays: Feminizing the pastoral in Eliot's The mill on the Floss, in S. Fuller \& J. Losseff (reds.), The idea of music in Victorian fiction (2004), p. 129. Vergelyk ook die eerste paragraaf van die vorige afdeling waar 'n verbandhoudende uitspraak van Van Niekerk ingesluit is. 
Agaat aangehaal om 'n atmosfeer of 'n situasie te teken. Dit plaas die roman midde-in 'n Afrikaanse plattelandse milieu.

Agaat gebruik verwysings na Afrikaanse volkswysies dikwels op 'n kwetsende en ironiese wyse. (Dit is wel nie die enigste manier waarop sy op Milla wraak neem nie.) Sy het 'n appeltjie met Milla te skil, want Milla het vir Agaat eers as “dogter” aanvaar, maar daarna na die buitekamer laat uittrek toe Milla se seun, Jakkie, gebore is. Wanneer Milla op haar doodsbed lê, sing Agaat: "Kom ons gaan blomme pluk in die vlei", ${ }^{59}$ wel wetend dat Milla dit baie graag sou wou doen, maar nie daartoe in staat is nie. "Japie my skapie, sing sy, die son sak weg, daar anderkant die blou berge”. ${ }^{60} \mathrm{Dit}$ terwyl Milla se lewe ("son”) besig is om weg te sak. Die woorde "Daar lê die ding" uit die lied Die een kant op en die ander kant af word deur Agaat gebruik wanneer sy probeer om Milla reg te laat lê op haar bed. ${ }^{61}$ "So lank as die lepel in die pappot staan” is die woorde wat Agaat gebruik wanneer sy met 'n roomysstokkie Milla se tong platdruk sodat sy in Milla se mond kan kyk. ${ }^{62}$ "Die trane die rol oor jou bokkie" sing Agaat terwyl Milla se wange nat is. ${ }^{63}$ Sy gaan voort met die liedjie terwyl sy Milla se tande borsel: "Daar waar die son en die maan ondergaan” en "Bokkie ek moet huis toe gaan" (in plaas van "Bokkie jy moet huis toe gaan”). ${ }^{64}$ Deur die sing van volksliedere probeer Agaat ook om die moeilike omstandighede vir haar en vir Milla draagliker te maak.

Nadat Agaat Milla se hare gesny het, beskryf Milla die toneel so:

Ook maar suinig met komplimente vanaand, sê Agaat, gebruik jou verbeelding, sê sy. Jy lyk mos kompleet na Julie Andrews.

The hills are alive with the sound of music, neurie Agaat. Een frase, dan verander sy haar wysie.

\section{Tant Koek se hoenderhaan. ${ }^{65}$}

Hier word verwys na die kort haarstyl van die filmster Julie Andrews in die rolprent The sound of music waar sy die lied "The hills are alive with the sound of music" sing. Tant Koek se hoenderhaan word tradisioneel by troues vir die arme bruidegom gesing

\footnotetext{
M. van Niekerk, Agaat (2004), p. 458.

M. van Niekerk, Agaat (2004), p. 460.

M. van Niekerk, Agaat (2004), p. 41.

M. van Niekerk, Agaat (2004), p. 46.

M. van Niekerk, Agaat (2004), p. 63.

M. van Niekerk, Agaat (2004), p. 64.

M. van Niekerk, Agaat (2004), p. 352.
} 
om aan te dui hoe beteuterd hy daar uitsien. Hierdie tipe netwerk van verwysings kom dikwels in Agaat voor.

Wanneer Agaat Milla se nie-samewerkende arms oefening moet gee, sê Agaat "Windpomp in die suidoos, [...] windpomp in die noordwes. Iksjee, iksjee, iksjee. Water in die dam, modder in die sloot, trap op haar kop, dan is sy dood.”66 Met "trap op haar kop, dan is sy dood” haal Agaat woorde uit die Afrikaanse volkswysie Siembamba, mamma se kindjie aan. En wanneer Agaat aan Milla se voete werk, sing sy: "Haar voete gaat na Wellington [...], maar sy gaat Worcester toe”, ${ }^{67}$ 'n aanpassing van "My voete gaan na Wellington, maar ek gaan Worcester toe”. Die bekende volksliedjies word byna altyd, soos hier, deur Agaat op 'n "wrede” manier gebruik: Milla is nie in staat om haar voete te gebruik nie.

Vir die moeilike oefening om Milla in die bad te kry, gebruik Agaat as “agtergrondmusiek" die liedjie Die blink vosperd: ${ }^{68}$

Wat hang jy daar tussen hemel en aarde, Ounooi? Is jy al weer aan die spoke sien? het sy gesê. Kom nou, ek kan nie my hele lewe lank hier op my hurke sit nie. Klim op! Blinkvosperd!

[...]

Want jy het gesê as ek jou wil hê, dan moet ek jou kom haal, het sy gesing. [...]

O, ék het 'n perd!

[...]

Op my mooi ryperd. My blinkvospe-e-e-rd, met die splinternuwe saal! [...]

Toe klim sy met my in die bad.

Skoene en al. ${ }^{69}$

Die oorspronklike eerste strofe van (toevallig) Van Niekerk se gedig lui:

O, ek het 'n perd, 'n blink vosperd

met 'n splinternuwe saal;

en ek klim op my perd, my blink vosperd, en ek kom om jou te haal.

Want jy’t gesê as ek jou wil hê dan moet ek jou kom haal

\footnotetext{
$66 \quad$ M. van Niekerk, Agaat (2004), p. 89.

67 M. van Niekerk, Agaat (2004), p. 89.

68 A.C. Hartman et al., FAK-Sangbundel (1979), pp. 308-309.

69 M. van Niekerk, Agaat (2004), pp. 556-557.
} 
op 'n mooi ryperd, 'n blink vosperd, met 'n splinternuwe saal.

Van Niekerk pas die oorspronklike F.A.K.-teks aan en ruil die versreëls om. Dit herinner aan die uitspraak van Kristeva: "Any text is the absorption and transformation of another." ${ }^{\text {70 }}$ Die voorafgaande aanhaling is 'n voorbeeld van 'n prosedure wat Van Niekerk ook met haar gebruik van versreëls uit Duitse kunsliedere toepas, soos uitgewys deur Van der Mescht. ${ }^{71}$

Die konteks van 'n troue op 'n boereplaas word geskets deur die noem van liedere wat daar gesing is:

Op die ou end het hy [Jak, Milla se bruidegom] al tweehonderd bruilofsgaste aan die sing gehad. $\mathbf{O}$ boereplaas, geboortegrond, het dit gedawer daar oor Grootmoedersdrift se werf, jou het ek lief bo alles. ${ }^{72}$

Hierdie lied (oorspronklik die Duitse lied Der Tannenbaum) vorm deel van die Afrikaanse kultuur nadat dit in 1927 in Joan van Niekerk se Die Groot AfrikaanseHollandse Liederbundel verskyn het, ${ }^{73}$ en in 1937 in die F.A.K.-Volksangbundel opgeneem is. ${ }^{74}$ Die woordteks is van C.F. Visser.

Milla, 'n persoon wat baie gebonde voel aan haar plaas, word sterk geïnspireer deur hierdie soort liedere. Sy skryf in haar dagboek oor die tyd toe sy Agaat se buitekamer reggekry het sodat Agaat daar kan bly:

Die ou FAK het my bietjie opgebeur. Het saggies dat niemand my hoor nie daar agter vir myself sit en liedjies sing. Die brug op ons plaas ${ }^{75}$ Op die dood van die uil ${ }^{76}$ Op my ou ramkietjie ${ }^{77}$ By die ou meulstroom. ${ }^{78}$ Sal dit haar

J. Kristeva, Word, dialogue, novel, in T. Moi (red.), The Kristeva reader (New York, 1986), p. 36.

71 H. van der Mescht, Verwysings na klassieke musiek in Marlene van Niekerk se roman Agaat (2009), pp. 7-11.

72 M. van Niekerk, Agaat (2004), p. 52.

73 J. van Niekerk, Die groot Afrikaanse-Hollandse liederbundel (Kaapstad, 1927), pp. 128-129.

74 Die F.A.K.-Volksangbundel (1937), p. 27.

75 Hierdie vier liedere kom almal in Die F.A.K.-Volksangbundel van Gutsche et al. (1958) voor. Die teks van Die brug op ons plaas (pp. 98-99) is van P.I. Hoogenhout. Die musiek van die Engelse volkswysie The old rustic bridge is verwerk deur Joan van Niekerk. Vir die FAK-Sangbundel van 1979 (A.C. Hartman et al., pp. 262-263) is die verwerking deur G.G. Cillié gemaak.

76 Gutsche et al., Die F.A.K.-Volksangbundel (1958), pp. 220-221. Die teks is van P.H. Langenhoven en is deur F. Axenfeld as "Hopp Marjannchen” getoonset.

77 Gutsche et al., Die F.A.K.-Volksangbundel (1958), p. 257. Die teks van C. Louis Leipoldt is deur Jan Bouws getoonset.

78 Volgens Gutsche et al., Die F.A.K.-Volksangbundel (1958), pp. 242-243, is die teks van C. Jacobs-Bond en die toonsetting deur Tell Taylor. Hierdie inligting word egter gewysig in A.C. Hartman et al. se 
[Agaat] ook troos? Die idee dat sy daar agter alleen sal sit en sing. Toe sit ek die sangbundel weer weg want toe wil ek weer net huil. ${ }^{79}$

Daar word ook uit die destydse amptelike volkslied, Die Stem van Suid-Afrika, aangehaal terwyl Agaat met die sterwende Milla op haar bed werk. ${ }^{80}$ Die reëls is geneem uit die derde strofe:

Ek wens ek kan terugpraat met haar, my eie idiome teenwerp.

\section{Met die kluitklap op die kis.}

\section{In die lanfer van ons rou.}

Ek pleit met my oё.

Sy wil nie na my kyk nie. Sy kyk vir haar handdoeke. ${ }^{81}$

Hier word weer eens slegs party van die versreëls gekies en dan in 'n ander volgorde aangebied. Daar ook 'n verandering in die teks: "by die kluitklap op die kis" word "Met die kluitklap op die kis". Die oorspronklike derde strofe van Die Stem van Suid-Afrika begin so:

In die songloed van ons somer,

in ons winternag se kou,

In die lente van ons liefde,

\section{in die lanfer van ons rou,}

By die klink van huw'liksklokkies,

\section{by die kluitklap op die kis}

Streel jou stem ons nooit verniet nie, weet jy waar jou kinders is. ${ }^{82}$

Agaat gebruik die sing van Afrikaanse volksliedjies om haar werk by die verstelling van Milla se bed vir haarself makliker te maak. In een van hierdie virtuose passasies haal Van Niekerk die eerste strofe van die woordteks van die Afrikaanse liedjie Aai, aai, die Witborskraai aan. Die eerste strofe lui so:

FAK-Sangbundel (1979), pp. 271-274. Volgens hierdie bron is die digter onbekend en is die teks deur Philip McLachlan gewysig. Die musiek is deur G.G. Cillié verwerk.

79 M. van Niekerk, Agaat (2004), p. 78.

$80 \quad$ H. Gutsche et al., Die F.A.K.-Volksangbundel (1958), pp. 27-28.

81 M. van Niekerk, Agaat (2004), p. 198.

82 H. Gutsche et al., Die F.A.K.-Volksangbundel (1958), pp. 27-28. Die gedig is van C.J. Langenhoven en die toonsetting deur M.L. de Villiers. 


\begin{abstract}
Aai, aai, die Witborskraai!
Hiervandaan na Mosselbaai

Hoog gevlieg en laag geswaai,

By die groot see omgedraai. ${ }^{83}$
\end{abstract}

Soos voorheen aangedui, word die versreëls hier ook met die res van die Agaat-teks vermeng:

Aai, aai, begin sy sing, saggies, op 'n ingetrekte asem. Maar die witborskraai kom nie, val weg in die leegte, Agaat se gesig verkrummel, haar kep verlep, haar mond gaan oop, gekwes.

'n Bondeltjie been en vere val sy, af deur die blou en die wit van die lugte, die bruin horison 'n tollende waas, af, af, af, swart-en-wit, 'n suiseling, voor sy tot haarself kom en haar vlerke oopmaak en die lug haar opbaar en sy weer kan vlieg.

Agaat se voet vind die pedaal, haar hand vind die vleuelmoer. Die bed kom met 'n suisgeluid en 'n ligte skok regop.

Sy sit my arms langs my sye. Vlerke waarmee ek nie kan vlieg nie.

Hiervandaan na Mosselbaai, hervat sy op die regte noot, die kraai 'n vanselfsprekendheid, oorgeslaan, uitgelaat uit die teks, maar sonder skade, want 'n liedjie wat ons al twee ken, dié kan dit alte goed verdra.

\title{
Hoog gevlieg en laag gedraai. ${ }^{84}$
}

Watse lap sal dit wees wat daar opgerol hang? Agaat se dekor vir die groot asemhalingstoneel? Dit sal die eerste handgemaakte versiering wees wat weer in my kamer hang nadat sy alles hier uitgedra het.

\section{By die groot see omgedraai.}

Sy maak die gespe van die masker agter my kop los. En die rek oor my neus. Een hand is op my bors besig om liggies ritmies te druk en te los. Dis die swak hand. Dit voel soos 'n voël wat op my sit, kleiner as 'n kraai, groter as 'n vink, 'n spreeu miskien. Die spreeu help my asem.

So ja, so kom ons om, so kom ons om. Knip vir my, Ounooi, knip met jou oë of jy regkom.

\footnotetext{
83 H. Gutsche et al., Die F.A.K.-Volksangbundel (1958), p. 429. Die teks is deur C.J. Langenhoven met musiek van S.H. Eyssen (een van die samestellers van Die F.A.K.-Volksangbundel van 1958). Volksangbundel (1958), p. 429. In 'n telefoononderhoud (2010-10-29) erken Van Niekerk dat sy hier 'n fout begaan het. Matilda Burden (p. 34) wys egter daarop dat volksliedere dikwels variante in die woordteks vertoon. Kyk M. Burden, Kenmerke van die Afrikaanse volkslied (1993), pp. 34-38.
} 
Sy hou my oë vas terwyl die sterk hand die masker opsy lê. Die sterk hand vervang die swak hand op my bors. Groter as 'n vink. Groot blink vlerkslag. Witborskraai.

Hiervandaan. Tot by die muur, tot wat daar hang.

Nóú, sê Agaat, nóú smaak dit my mos gaan dit weer voor die wind met jou saam. ${ }^{85}$

In die voorafgaande uittreksel is elke versreël van die woordteks in die oorspronklike volgorde ingelyf, waarna die woorde "Witborskraai" en "Hiervandaan" toegevoeg is. Hierdie "mosaïek van aanhalings" (so genoem deur Kristeva: "any text is constructed as a mosaic of quotations") ${ }^{86}$ word dikwels deur Van Niekerk gebruik.

Agaat sing gereeld wanneer sy werk, soos in die volgende aanhaling uit Milla se dagboek:

A. stap gelykvoets aan die kant van die ploeg met hr sterk hand op die handvatsel \& hr skouer hoog opgetrek \& praat met die muil \& sing dat dit weergalm: Bobbejaan klim die berg om die boere te vererg. ${ }^{87}$

Hierdie verwysing dra moontlik politieke ondertone, aangesien die woord "boere" deur baie Kleurlinge (die groep waartoe Agaat behoort) as verwysend na witmense gebruik word.

Ander vaderlandsliedere wat genoem word, is die Vlaglied deur die beginwoorde "Nooit hoef jou kinders wat vry is te vra". ${ }^{88}$ Die korrekte teks is "Nooit hoef jou kinders wat trou is te vra". ${ }^{89}$ Van Niekerk verklaar in 'n telefoononderhoud dat sy die verandering met opset aangebring het. ${ }^{90}$ Waar dit in die roman oor die bevryding van Agaat van haar gebondenheid en onderdanigheid aan Milla gaan (en ook Milla se bevryding van haar gebondenheid aan Agaat) is die veranderde woord goed gekies.

Daar word nie vriendelik gewerk met die eerste versreëls ("En hoor jy die magtige dreuning? Oor die veld kom dit wyd gesweef”) van die patriotiese Die lied van Jong Suid-Afrika nie. ${ }^{91}$ Dit is in die passasie waar beskryf word hoe moeilik dit vir Agaat is om Milla se hardlywige maag aan die gang te kry:

M. van Niekerk, Agaat (2004), pp. 225-226.

J. Kristeva, Word, dialogue, novel (1986), p. 36.

M. van Niekerk, Agaat (2004), p. 234; A.C. Hartman et al., FAK-Sangbundel (1979), p. 307.

M. van Niekerk, Agaat (2004), p. 227.

M. Casaleggio (hoofred.), Goue gerf (1970), pp. 6-8.

M. van Niekerk, telefoononderhoud, 2010-10-29.

H. Gutsche et al., Die F.A.K.-Volksangbundel (1958), p. 35. Die gedig is van Eitemal en die musiek van Gutsche. 
Hoor jy, sê sy op 'n ingetrekte asem, hoor jy die magtige dreuning?

[...]

\section{$[\ldots]$ Oor die veld kom dit wyd gesweef. ${ }^{92}$}

Agaat se keuse van Afrikaanse volkswysies is gewoonlik hoogs ironies en kwetsend. Hier is 'n toneel voordat Milla bedlêend geword het:

Met die vierpuntkierie [...] het dit al veel langer gevat. Die loopraam was uiteindelik 'n halfuur se gestoei. As ek begin aanstaltes maak het en die eerste gestommel het op die vloerplanke geklink, het Agaat begin sing. Aanstap rooies, die pad is lank en swaar. ${ }^{93}$

Hierdie woorde beskryf nie net die moeilike pad wat Milla op daardie oomblik moes aflê nie, maar ook die aard van Agaat en Milla se verstrengelde lewens.

\section{Gevolgtrekking}

Van Niekerk se roman Agaat is 'n buitengewoon verwikkelde werk waarin verwysings na musiek 'n baie groot rol speel. Hierdie verwysings het te doen met die volgende: ligte liedere; psalms, gesange en hallelujaliedere; verwysings na spesifieke komposisies uit die klassieke repertorium; verskuilde, vertaalde aanhalings van versreëls uit getoonsette gedigte uit die Duitse kunsliedrepertorium; maar ook opvallend dikwels met Afrikaanse volksliedere. Hierdeur word die milieu waarin die roman afspeel, beklemtoon en word die kulturele (Afrikaanse) konteks benadruk.

Die woordtekste word op uiters vernuftige wyse in die teks geïntegreer. Soos aangetoon, is Van Niekerk 'n meester by die “toevallige” inkorporering van versreëls uit Afrikaanse volksliedere. Die verhouding tussen die karakters Agaat en Milla word blootgelê deur die gebruik van die woordtekste van Afrikaanse volkskliedere, meesal geneem uit die Die F.A.K.-Volksangbundel van 1958. Agaat gebruik gereeld hierdie metode om die belêende Milla te treiter, nadat sy ('n "Kleurling”) eers as "dogter" binne die huis aanvaar is, en daarna tot "bediende” met 'n buitekamer gedemoveer is toe Milla se eie seun, Jakkie, gebore is. Op hierdie manier neem Agaat wraak op die weerlose Milla. Die lawwe verwysings na Afrikaanse volksliedere kan ook 'n metode wees waardeur Agaat haar verleentheid in die intieme tonele wegsteek.

M. van Niekerk, Agaat (2004), p. 417.

M. van Niekerk, Agaat (2004), p. 552. 
Van Niekerk verander soms die woordteks, bloot deur 'n woordfout te maak (soos in die liedjie Aai, aai, die Witborskraai) of doelbewus, soos by die aanhaling van "Nooit hoef jou kinders wat vry is te vra" in plaas van "Nooit hoef jou kinders wat trou is te vra". Hier dra die woord "vry" belangrike betekenis oor, aangesien die hoofkarakter Agaat vry wil wees van die lewe saam met Milla, en Milla smag na die verlossing uit haar eie armsalige lewe.

Die vraag is of Van Niekerk dit reggekry het om 'n Afrikaanse kultuur deur middel van die aanhalings van uittreksels uit die woordtekste van Afrikaanse volksliedere te teken. Dit is my mening dat Van Niekerk dit op 'n uitstekende wyse vermag het. Deur die voortdurende verwysing na Afrikaanse volksliedere deur middel van die "toevallige" insluiting daarvan in die teks, laat sy die leser nooit vergeet nie dat dit hier om 'n Afrikaanse roman oor “gewone” Afrikaanssprekendes in 'n Afrikaanse milieu gaan. Ná Agaat is dit te betwyfel of enige skrywer weer so uitgebreid van verwysings na die woordtekste van Afrikaanse volksliedere gebruik sal kan maak. 